\title{
LINKING RELIEF AND DEVELOPMENT: AN ETHIOPIAN CASE STUDY
}

Simon Maxwell and Alemayehu Lirenso

\section{INTRODUCTION}

The idea of linking relief and development (LRD) is immediately attractive in Ethiopia, and, indeed, to Ethiopia. Here we have a very poor country, which has suffered repeated food shocks and where emergency relief has played a dominant role in aid programmes. What more sensible idea than to adopt the basic principles of LRD: directing development to the reduction of vulnerability, and relief to the enhancement of long-term development?

One statistic illustrates the potential synergy. Ethiopia has typically received one million tons of food aid in a drought year, almost exclusively for direct distribution as relief. If used instead as a wage on food for work, one million tons of food would be enough to pay for over three hundred million days of work at standard work norms. A workforce of this size could build $167,000 \mathrm{~km}$ of access road or $417,000 \mathrm{~km}$ of artificial waterway or 2,700 earth dams, all in a single year. These are assets which would not otherwise be built and which could contribute to more secure livelihoods and lower vulnerability in the future.

The temptation is to plunge straight from statistics like these into a detailed discussion of how develop- ment programmes must be modified and relief programmes improved. However, a policy and programmatic focus obscures deeper issues which deserve a more thorough airing. Three of these are our focus here and together suggest that LRD is not quite as straightforward as it is sometimes portrayed to be. First, there are inevitable trade-offs, between social groups, geographical regions and time periods, as well as between growth and variability. Secondly, there are questions about what is feasible in different kinds of country; and hence about the pace and sequence of LRD interventions. And, thirdly, issues arise about institutional development, and particularly about the question 'who does what'.

\section{FOOD SHOCKS AND VULNERABILITY IN ETHIOPIA}

In terms of a country typology (Buchanan-Smith and Maxwell in this volume), Ethiopia is a poor country, with acute food insecurity and weak state capacity. Its problems result largely from decades of civil war, exacerbated by drought and the erroneous policies of the Marxist Government, overthrown in 1991. Table 1 illustrates those problems: even in

\begin{tabular}{|c|c|c|}
\hline Indicator & Ethiopla & SSA \\
\hline GNP/Cap (\$US, 1992)! & 110 & 530 \\
\hline Intant mortality rate $(0 / 00,1992)$ ) & 122 & 99 \\
\hline Adult literacy $(\%, 1990)^{2}$ & 24 & 51 \\
\hline$\%$ enrolment in primary school (1991)' & 25 & 66 \\
\hline $\begin{array}{l}\text { Daily calorie supply as \% requirement } \\
(1988-90)^{2}\end{array}$ & 73 & 93 \\
\hline $\begin{array}{ll}\text { Source: } 1 \text { World Bank, World Developm } \\
& 2 \text { UNICEF, State of the World's }\end{array}$ & $\begin{array}{l}\text { ort, } 1994 \\
\text { Report, } 1994\end{array}$ & \\
\hline
\end{tabular}




\section{Figure 1: Food insecurity in Ethiopia 1992, by category}

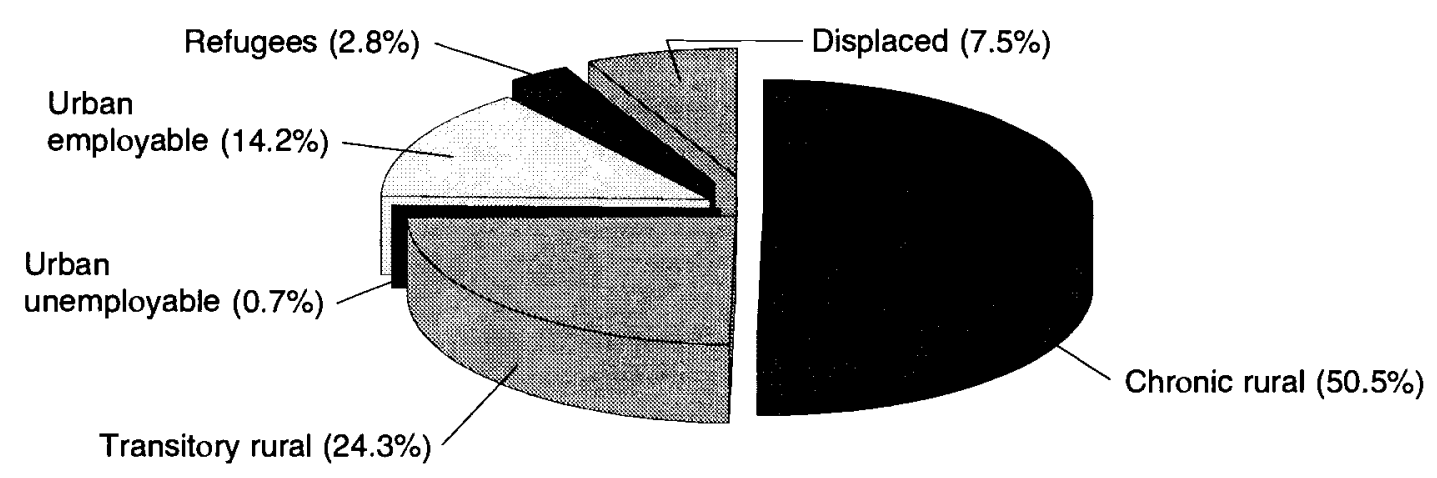

Source: Debebe and Maxwell 1992

comparison with other countries in SSA, Ethiopia has a low per capita income and poor social indicators.

The consequence of low growth and repeated shocks to the food system is that large numbers of people are food insecure in Ethiopia. A recent analysis suggested that around 27 million people in Ethiopia might be food insecure in 1992, equivalent to around 55 per cent of the national population (Debebe and Maxwell 1992). The main groups are illustrated in Figure 1: resource-poor rural households living in chronic poverty form the largest group, followed by those with greater resources but high exposure to shocks. ${ }^{1}$ The urban poor form a large group, growing under the impact of structural adjustment, the divestiture of state enterprises and the removal of restrictions on rural-urban migration. Refugees, the displaced and demobilized soldiers are also important groups, in a country recovering from a long civil war. Food insecurity is concentrated in resource-poor regions, mostly on the margins of the central highlands (Debebe and Maxwell ibid).

Food insecurity is exacerbated by frequent food shocks and by declining food availability per capita. Cereal, pulse and oilseed production data in Figure 2, for the period 1979/80 to $1991 / 92$, show stagnating production overall and a declining per capita trend, with three major shocks in a thirteen year period

1 For examples of vulnerability analysis see CARE 1993, Webb et al 1994.
(Gutu 1993). 1992/93 was a record year, but 1993/ 94 a poor one, with a food deficit of over 1 million tons: 7 million people were estimated to need food assistance (FEWS 1994: 39ff, FAO 1994).

Food aid flows have historically reflected the high variability of production and the recurrent relief need. On WFP data, they have not fallen below 600,000 tons p.a. since 1984/85 (Aylieff 1993). Food aid alone accounted for more than 20 per cent of all aid received by Ethiopia in the years 1987-89 (World Bank/WFP 1991:7). A notable feature of food aid for emergency relief is that nearly all (an estimated 80 per cent in 1984/85) was channelled through NGOs rather than through the Government's Relief and Rehabilitation Commission (RRC). This conclusion still held as recently as 1992 (Aylieff ibid: para 16).

Relief has been expensive in Ethiopia: in the peak year of 1984/85, the external cost alone of food, transport, and non-food items was estimated to exceed \$US 400 million: this was equivalent to $36 \mathrm{per}$ cent of total government revenue in $1984 / 85$, or 94 per cent of total capital expenditure in the same year (Maxwell and Belshaw 1990:2). About eight million people were identified by the RRC as being in need of relief in 1985. This gives an external relief cost per person of about \$US 50, comparable to figures reported for other relief operations. ${ }^{2}$

\footnotetext{
${ }^{2}$ A figure of \$US 35 per head is reported for the Southern African drought of 1991/92, a slightly lower figure for what appeared to be a much more successful relief operation (John Mason, personal communication).
} 
Figure 2a: Cereal, pulse and oilseed production 1979/80 - 1991/92: total domestic production

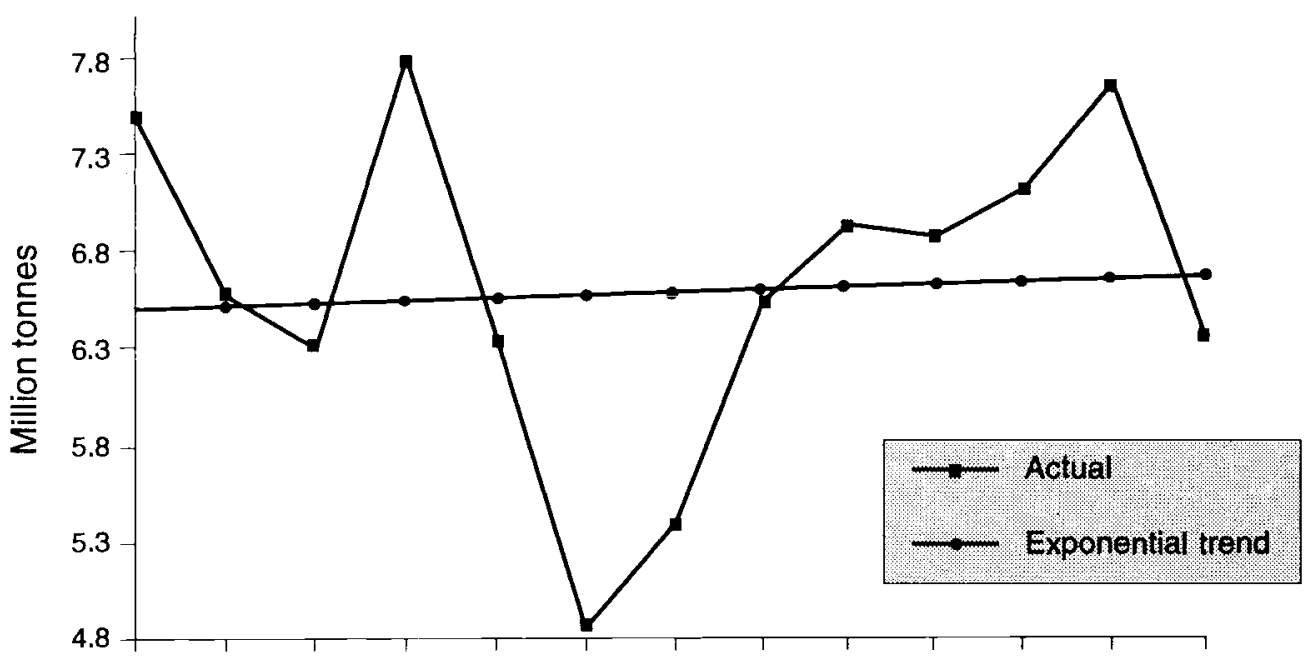

$\begin{array}{llllllllllllllll}1979 / 80 & 1980 / 81 & 1981 / 82 & 1982 / 83 & 1983 / 84 & 1984 / 85 & 1985 / 86 & 1986 / 87 & 1987 / 88 & 1988 / 89 & 1989 / 90 & 1990 / 91 & 1991 / 92\end{array}$

Year

Source: Gutu 1993

Figure 2b: Cereal, pulse and oilseed production 1979/80 - 1991/92: per capita domestic production

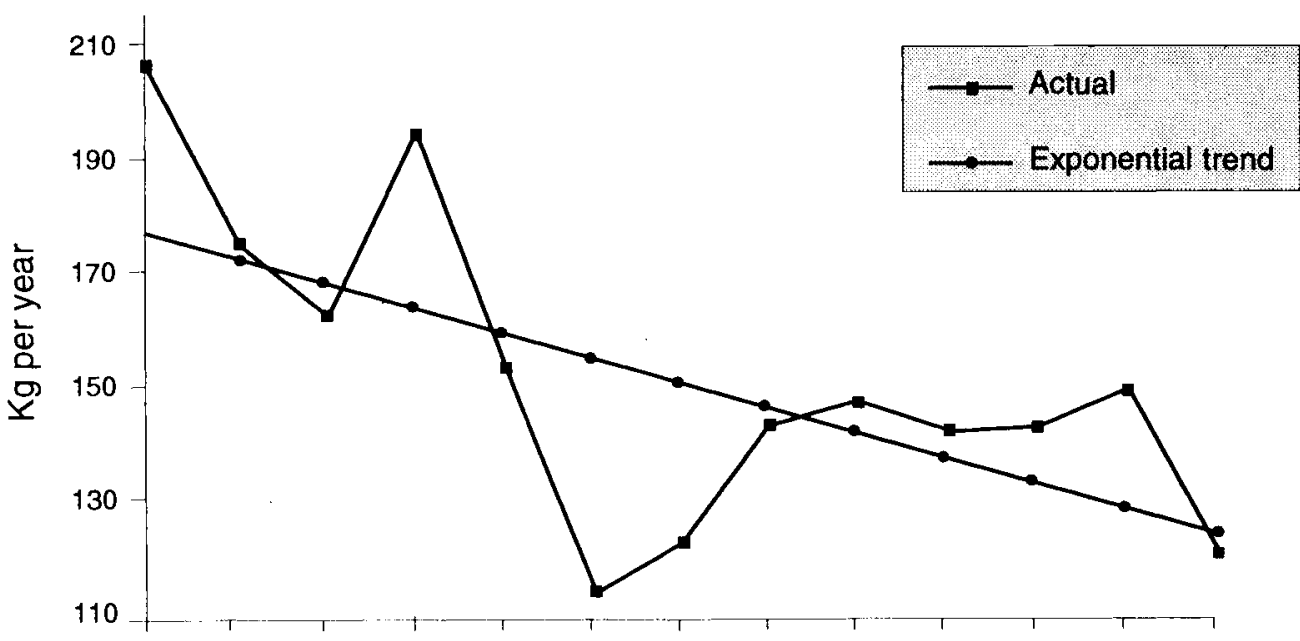

$\begin{array}{llllllllllllll}1979 / 80 & 1980 / 81 & 1981 / 82 & 1982 / 83 & 1983 / 84 & 1984 / 85 & 1985 / 86 & 1986 / 87 & 1987 / 88 & 1988 / 89 & 1989 / 90 & 1990 / 91 & 1991 / 92\end{array}$

Year

Source: Gutu 1993 


\section{LINKING RELIEF AND DEVELOPMENT IN ETHIOPIA}

LRD is not a new topic in Ethiopia. The Relief and Rehabilitation Commission, established in 1974, became a model in SSA. Work began soon after the drought of 1984/85, on both a National Food and Nutrition Strategy (NFNS) and a National Disaster Prevention and Preparedness Strategy (NDPPS) (Belshaw 1990): the former contained measures to reduce poverty and vulnerability, the latter, measures to make relief more developmental. Both, however, became caught up in the policy turmoil surrounding the fall of the Mengistu Regime and the establishment of the Transitional Government (TGE) in 1991.

Since 1991, the overall policy stance in Ethiopia has swung from a high degree of state intervention to the pursuit of a liberalized and market-based economy (TGE 1991). The shifts in food security policy are traced in Figure 3. Many of the familiar features of Ethiopian Government policy in the 1980s have been abandoned: encouragement of state farms and producer co-operatives; restrictions on private land ownership and labour rental; procurement quotas and fixed prices; controlled markets and urban rations. There have been short-term losers in the process of adjustment and liberalization, including among the urban poor who have been deprived of the safety net provided by the public distribution system. However, safety-net issues apart, the array of currently-stated policies is consistent with most international thinking on food security in Africa (Maxwell 1992, von Braun et al. 1992).

The formal NFNS has not yet been finalized. However, the NDPPS has progressed, in the form of a National Policy on Disaster Management (NPDM) and Directives for Disaster Prevention and Management, both approved in 1993 (TGE 1993 a,b). LRD is an explicit objective of these documents, which set out to ensure that 'relief assistance is provided to the affected population in a manner which ensures that such efforts contribute towards disaster prevention and sustainable growth and development, and that disaster prevention efforts get due attention in the government's development efforts' (TGE 1993b: 1).

The centre-piece of the NPDM is a new employment generation scheme (EGS), which is to be the main form of assistance to the able-bodied. In principle, free relief is to be limited to the aged, the infirm, the disabled, pregnant women, young children, and persons who are required to attend constantly on young children or incapacitated adults (TGE 1993a:8). Complementary measures are to includewater, health and agricultural interventions (TGE 1993b).

Practice lags inevitably behind policy. Furthermore, there are competing pressures on policy-makers, especially in the realm of macroeconomic stabilization and structural adjustment. Devaluation, liberalization and closing down state enterprises have been higher on the agenda than, say, increasing budgets for agricultural research into drought-resistant crops. In addition, policy implementation has been hampered by delays in deciding and putting into effect a new constitutional settlement, based on devolution to new administrative regions, which are still very weak. As a result, many of the detailed policies described are not yet operational and may never become so. Even those that are becoming active, like the proposal for employment generation schemes, will take many years to achieve wide coverage.

\section{ISSUES IN LINKING RELIEF AND DEVELOPMENT}

There is much to say about individual elements of the LRD programme: farming systems development in drought-prone areas (Belshaw 1990), employmentbased safety-nets (Herbinger 1993, Maxwell 1993), grain market stabilization (Alemayehu 1993), and the rest. The focus here, however, is on three crosscutting issues: costs and trade-offs; the pace and sequencing of LRD; and institutional issues.

\subsection{Costs and trade-offs}

Policy initiatives in LRD are often presented as if they were uniformly attractive in cost-benefit terms, or involved no trade-offs. This is patently not the case. The question is how big the trade-offs are and whether the costs are justified. Consider two examples.

\section{i The employment-based safety net}

At first sight, offering jobs rather than free food to those affected by drought appears highly attractive. However, it is not cost free.

The incremental costs over and above relief will include professional staff for the design of works, tools, supervision, non-food inputs and administration, both locally and centrally. These costs alone have been estimated to be at least 40 per cent of wage costs in Ethiopia (Maxwell and Belshaw 1990), though 


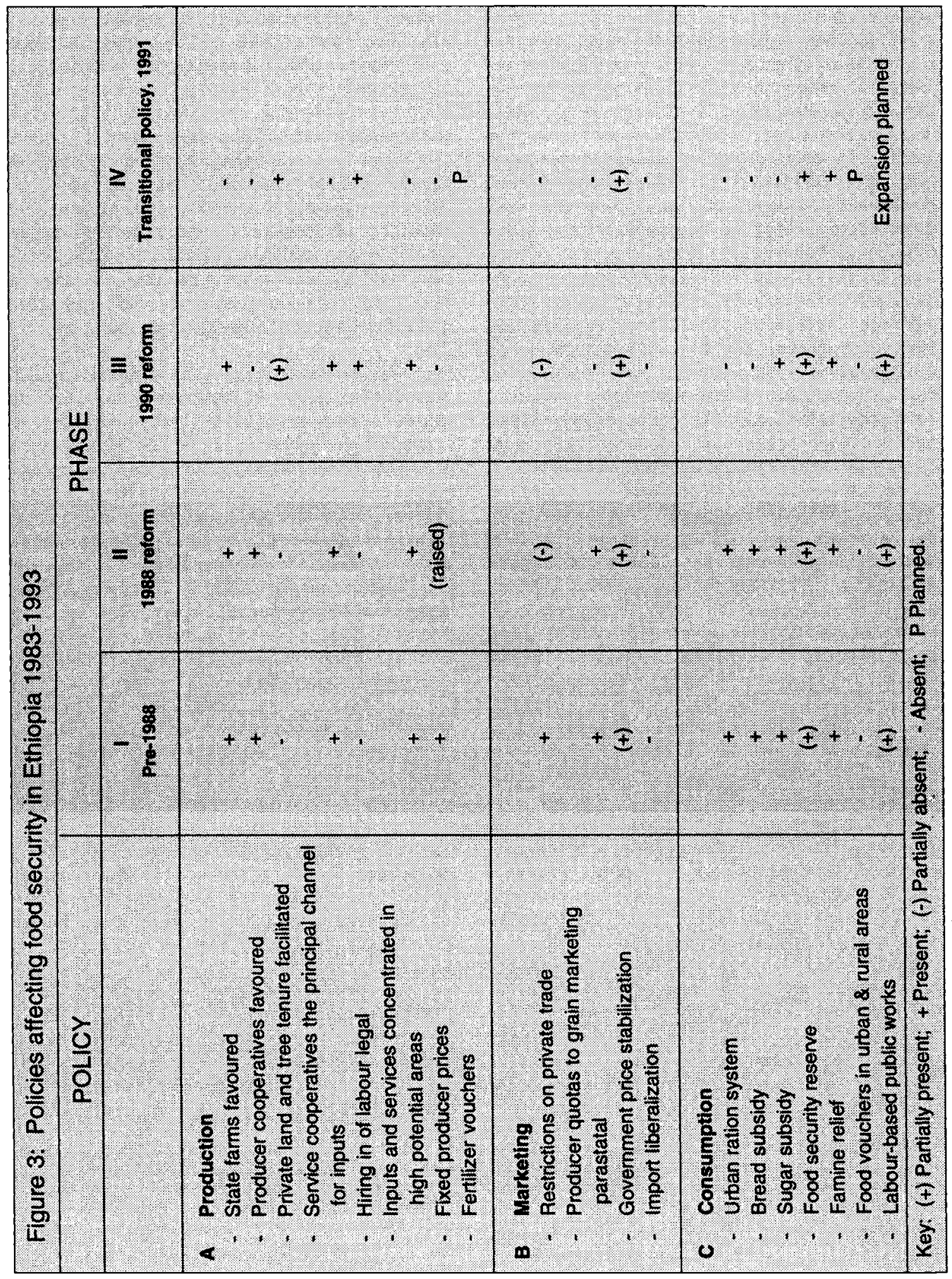


some of the administrative costs can be shared with relief programmes, and it is usually necessary for the two types of scheme to run in parallel, since not everyone can participate in public works. In addition, the physical effort involved in public works requires additional calories, perhaps as many as $1,000 \mathrm{Kcal}$ per worker per day, adding around 10 per cent to the food cost of a relief operation. ${ }^{3}$ Adding these together gives a cost of an employment-based safety net up to 50 per cent higher than simple relief, other things being equal. On the other hand, if basic food costs are covered by the relief programme, the incremental cost per day of an employment-based safety net (EBSN) is only one third of a normal public works programme, less if the administrative costs of relief are taken into account. ${ }^{4}$

At the same time, productivity on relief works is notoriously low, especially when work sites are open to all supposedly able-bodied people, including sometimes the elderly, children and the infirm. And the quality of the output is often low, with the long term benefit dissipated by poor maintenance. Such problems are well-known in Ethiopia (Webb et al. 1992: 106ff).

The question, then, is whether the benefit from public works justifies the incremental cost over and above relief. There can be no general answer to the question. There have been no specific calculations of the B:C ratio of EBSN projects in Ethiopia. Indeed, such calculations are notoriously difficult when one of the main activities is soil conservation, where the benefits are hard to measure (Blaikie and Brookfield 1987). All that can be said is that public works projects in general do have high rates of return (World Bank 1976). If the 'losses' on the side of low productivity and poor quality are matched by the 'gains' on the side of relatively low cost compared to other public works, then EBSN also should offer an acceptable cost-benefit ratio. ${ }^{5}$ However, this should not be taken for granted and will certainly depend on the type of work carried out. There will also be trade-offs to consider. For example, the easiest way to generate jobs in the short-term is through road construction: however, roads provide rather little long term employment,

\footnotetext{
${ }^{3}$ Assuming one worker supports five dependants and that an average relief ration provides $400 \mathrm{gm}$ of cereal per person per day, the extra grain required (about $250 \mathrm{gm}$ ) adds about ten percent to the relief cost $(2.4 \mathrm{~kg})$.

4 Calculated as the cost of the extra 1,000 calories, plus the non-wage costs.
}

and may therefore make only a small contribution to reduced poverty, though they may contribute to reduced vulnerability through better market integration. ${ }^{6}$

\section{ii Investment in low potential areas}

Another possible example of hidden costs is the frequent recommendation to target resources explicitly on vulnerable households in resource-poor areas. This is a feature of current Ethiopian government policy, not least for political reasons: the TGE's political base arose from rebel movements in Tigre and other ecologically marginal areas.

In principle, investment in low potential areas ought by definition to be less 'profitable' than investment in high-potential areas. The World Bank, for example, has suggested that the best solution to the problem of low potential areas is to encourage out-migration (World Bank 1990). It follows that investment in low potential areas may have a high opportunity cost in terms of growth elsewhere in the economy. On this argument, it is necessary only because people cannot be moved or because income transfers cannot be made.

To counter this, it is sometimes argued: that highreturn investments can be found even in low-potential areas, for example small-scale water resource development; that low-potential areas can be transformed into high-potential areas with large investments, like roads; or that investments in these areas are justified because of the saving on relief costs.

The last argument is especially persuasive and can easily be modelled. Say household income in a low potential area is $\$ 200$ p.a. and needs to be doubled to provide sufficient insurance against drought. Say also that the rate of return on investment in a low potential area is 5 per cent, compared to 10 per cent in a high potential area. It would therefore take an investment of $\$ 4000$ in the low potential area to raise the income of a household sufficiently to avoid the need for relief. Say that the cost of relief is $\$ 50$ per person and that there are six people in the household, giving a relief cost in drought years of $\$ 300$ per

\footnotetext{
${ }^{5}$ A back of the envelope calculation suggests that the wage saving on EBSN would be enough to cushion a project against a significant fall in the internal rate of return, despite a doubling of the time taken to finish a project and a long term productivity fall of $25 \%$ compared to a traditional public works project.

6 For a discussion of issues surrounding food and cash for work, see Clay 1986, Von Braun et al. 1992
} 
household. And say that there are three bad years in ten. Then, option A might be to invest $\$ 4000$ in the high potential area, generate additional income of $\$ 400$ per annum and spend $\$ 300$ twice in ten years to pay for relief; and option B to invest $\$ 4000$ in the low potential area, generate an additional $\$ 200$ per year and have no relief costs. On these assumptions, which are not implausible for Ethiopia, the internal rate of return is higher for investment in high potential areas, at 7 per cent compared to 5 per cent, despite the additional expenditure on relief and even when the three drought years occur at the worst possible time, at the beginning of each decade. This suggests a predisposition not to invest in low potential areas.

Of course, the calculation is only illustrative. The rate of return differential would be lower if the cost of drought-proofing households were lower, droughts more frequent than three in ten or the relief cost higher. Figure 4 explores some of these questions in a switching curve analysis, which shows how the choice between investment in high or low potential areas depends on (a) the frequency of drought and (b) the cost of relief. In the SW corner of the figure, where drought is infrequent and relief costs low, then, other things being equal, investment in high potential areas has a higher benefit:cost ratio; conversely, in the NE corner, where drought is more frequent and relief costs high, investment in low potential areas is more profitable.

A simple cost-benefit calcula tion provides only a first cut at these issues and a more sophisticated analysis is required to examine linkage effects. Similarly, there are other factors to take into account, including inter-regional equity. The point is not to draw a definitive conclusion, but to suggest that it is necessary to review the opportunity costs of different policies.

Many other examples could be drawn from the LRD agenda: the opportunity cost of holding a contingency fund to help cope with the macroeconomic destabilization caused by drought; a possible tradeoff between faster growth of agricultural output, perhaps based on intensification, and greater stability of output and farm income, perhaps based on diversification. These trade-offs remain unexplored.

\subsection{The pace and sequencing of LRD interventions}

LRD is sometimes presented as simple common sense: as if the only task were to think through how relief and development can be linked and then to do it. In fact, this omits an important discussion about what is feasible in different kinds of situation;

\section{Figure 4: Switching curve for investment, wht drcught frequency and rellef cost}

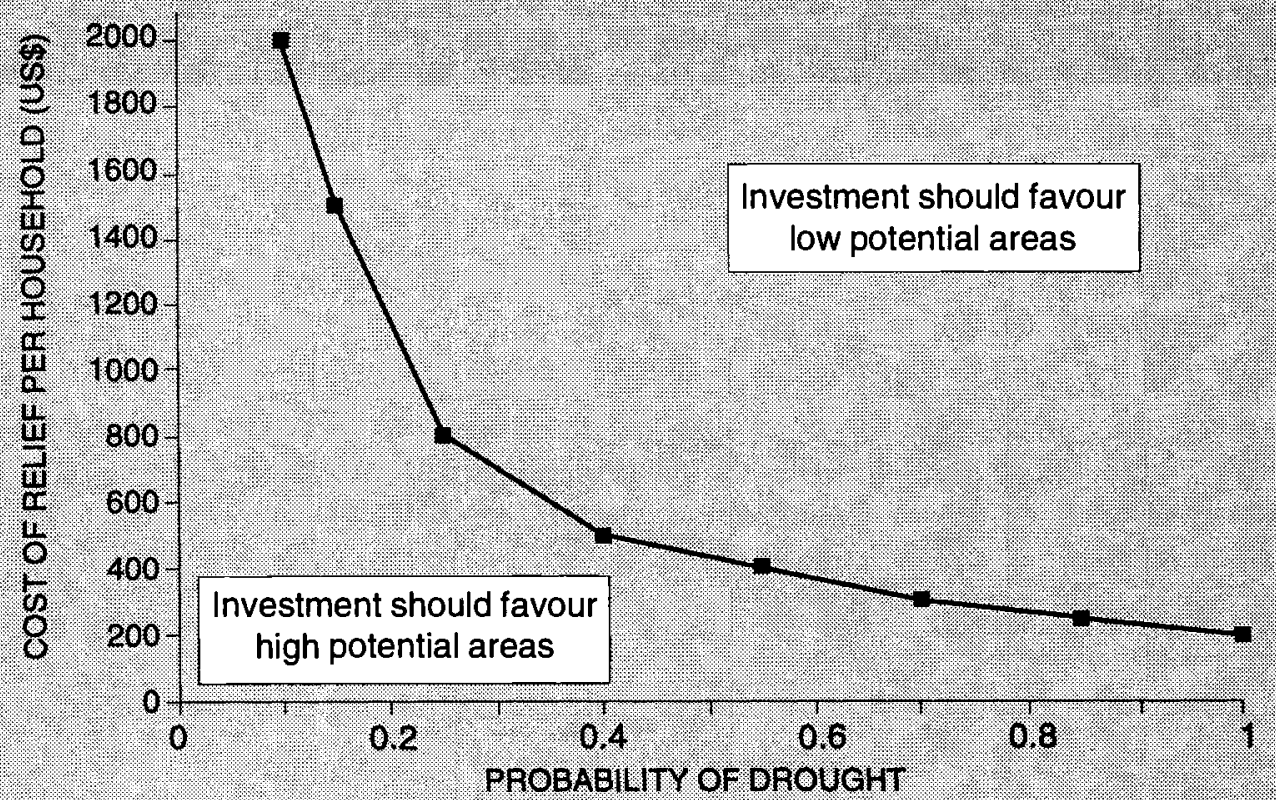


and may as a result impose impossible demands on governments and local organizations. To take an obvious example, what is feasible in Botswana, which is peaceful, well-administered and relatively rich, may not be feasible in Southern Sudan, which has none of these attributes.

Ethiopia has moved rapidly since 1989, from a highly interventionist policy stance to one which is liberalizing, from a relatively low to a higher commitment to poverty reduction, and from civil war to peace. Nevertheless, state capacity remains extraordinarily weak, in a country with poor communications, feeble social and physical infrastructure, a weak civil service and no resources.

In this context, many LRD policies, including some espoused by the TGE in its policy statements, are simply not feasible in the short term. Figure 5 explores some of the main options, listing the requirements and identifying the main constraints. These include the absence of accepted models, whether technological or administrative, the lack of implementation capacity, and severe budgetary constraints.

Figure 5 is not to be read as a defeatist analysis. The fact that good ideas cannot be implemented immediately does not mean that they are not good ideas, nor that they should not feature in policy. Ethiopia is making rapid progress on many of the items listed. The issue more is to focus on priorities and sequencing of the main interventions. The greatest danger, in Ethiopia, would be to try and do everything at once, and thereby do everything badly. A good example would be to decree that all relief must move immediately to an EGS format: this would certainly not be possible and would leave many vulnerable people brutally exposed to the risk of famine.?

Are there some principles which can be followed in pursuing the implementation of LRD in Ethiopia? Four suggest themselves:

First, the top priority must be to make sure that a basic relief safety net is operational throughout the country. This is the basic requirement to meet the objective of the NPDM, sadly not yet achieved, that'no human life shall perish for want of assistance in time of disaster' (TGE 1993b: 3). The key requirements for this are adequate information, decentralized response mechanisms at regional and woreda (district) level and national-level support. Only when the basics can be handled well is it legitimate to go on to think about linking relief with development.

Secondly, a bottom-up process is likely to produce the best prioritization of LRD activities at the local level. This suggests that regional and district level food security analysis and planning in required, to diagnose problems and prioritize solutions. Consistent with TGE policy, planning should be participatory and community-based.PRA methods have an obvious role to play (Chambers 1993).

Thirdly, a process of experimentation will be called for, with many pilot projects, intensive evaluation and widespread sharing of ideas. The RRC and other central government institutions may find themselves inspiring and co-ordinating experimentation and facilitating financial support, rather than mandating change from the centre. However, the poor should be protected from the risks associated with experimentation.

Finally, and again to be consistent with TGE policy, the emphasis will need to be on improved functioning of markets, with minimal administrative intervention. This suggests that the priorities in local planning will need to be on self-targeting, community-based social security, local adaptive research, deregulation of private trade and support to existing common property resource management.

\subsection{Institutional issues}

A final set of questions is about institutions. The conventional wisdom of discussions on LRD is that relief and development institutions operate independently and with different organizational cultures, and that ways should be found to bring them together (Buchanan-Smith 1990). Two further points arise: first, the relationship between government, aid donors and NGOs; and, secondly, the role of a co-ordinating organization like the Ethiopian Relief and Rehabilitation Commission.

In most discussions of LRD, the implication is that government will take on the main burden of institutional coordination. In real world cases, however, as in Ethiopia, the government has historically been a minor player, at least in relief, with donor-funded NGOs taking the main role. Indeed, foreign NGOs in Ethiopia have also taken a leading role in longer-

\footnotetext{
7 We are indebted to Julius Holt, who has made this point forcefully on many occasions.
} 
Figure 5: Constraints on LRD policies

\begin{tabular}{|c|c|c|}
\hline $\begin{array}{l}\text { Activity to link reliet } \\
\text { and development }\end{array}$ & Requirements & Constraints: \\
\hline $\begin{array}{l}\text { Increase absolute and } \\
\text { relative share of public } \\
\text { investment in low } \\
\text { potential areas }\end{array}$ & $\begin{array}{l}1 \text { Viable proposals } \\
2 \text { Political support } \\
3 \text { Budget } \\
4 \text { Administrative and extension } \\
\text { capacity }\end{array}$ & $\begin{array}{l}1 \text { Lack of research output and } \\
\text { planning capacity } \\
2 \text { Resistance from high } \\
\text { potential areas } \\
3 \text { Budget constraints } \\
4 \text { Weak government capacity } \\
\text { In low potential areas }\end{array}$ \\
\hline $\begin{array}{l}\text { Reduce coefficient of } \\
\text { variation of agricultural } \\
\text { output }\end{array}$ & $\begin{array}{l}1 \text { Suitable lechnologies } \\
\text { (varieties, irigation, elc.) } \\
2 \text { Extension programme } \\
3 \text { Public investment } \\
4 \text { Credit to farmers }\end{array}$ & $\begin{array}{l}\text { 1. Weak research base } \\
2 \text { Weak extension programme } \\
3 \text { Budget constraints } \\
4 \text { Lack of rural banking system }\end{array}$ \\
\hline $\begin{array}{l}\text { Establish a contingency } \\
\text { tund to olisel budgetary } \\
\text { shocks caused by } \\
\text { drought }\end{array}$ & $\begin{array}{l}1 \text { Revised monetary and financial } \\
\text { policy. } \\
2 \text { Avaliabilly of toreign exchange } \\
\text { and domestic resources }\end{array}$ & $\begin{array}{l}1 \text { higher priority given to } \\
\text { immediate liberalization and } \\
\text { stablization } \\
2 \text { Shertage of resources }\end{array}$ \\
\hline $\begin{array}{l}\text { Establish fully } \\
\text { Integrated grain narkets } \\
\text { backed by he Ethiopian } \\
\text { Grain Trading Enterpise } \\
\text { (EGTE) as buyer and } \\
\text { seller of last lesort? }\end{array}$ & $\begin{array}{l}1 \text { Aclequate physical infrastructuro } \\
\text { (roads, market centres) } \\
2 \text { Legal and administrative } \\
\text { Iramework favouring lade } \\
3 \text { Access to vehicles, inpurs, } \\
\text { credit by traders } \\
4 \text { Network of EGTE buying and } \\
\text { selling points throughoul } \\
\text { the country. } \\
5 \text { Finance and storage capacity } \\
\text { Ior EGTE }\end{array}$ & $\begin{array}{l}1 \text { Lack of resources and: } \\
\text { Technical skills to expand } \\
\text { Thrastructure at rate required } \\
2 \text { Residual adninitrativo } \\
\text { hurcles, especially at local } \\
\text { government level. } \\
3 \text { Lack of finance for traders } \\
4 \text { Severe constraints on } \\
\text { expansion of EGTE }\end{array}$ \\
\hline $\begin{array}{l}\text { Establish a national } \\
\text { employment generation } \\
\text { scheme }\end{array}$ & $\begin{array}{l}1 \text { Agreed procedures tor planning } \\
\text { and managing EGs } \\
2 \text { Planning and technical capacity } \\
\text { at local level } \\
3 \text { Food and cash resources for } \\
\text { implementation }\end{array}$ & $\begin{array}{l}1 \text { EGS still experimental } \\
2 \text { No local capacity } \\
3 \text { Severe resource constraints }\end{array}$ \\
\hline $\begin{array}{l}\text { Provide sustainable } \\
\text { health and water } \\
\text { interventions during } \\
\text { crisis periods }\end{array}$ & $\begin{array}{l}1 \text { Agreed plans of action } \\
2 \text { Local government implementation } \\
\text { capacity } \\
3 \text { Resources }\end{array}$ & $\begin{array}{l}1 \text { Still experimental } \\
2 \text { Local government very weak } \\
3 \text { Resources not yet avallable }\end{array}$ \\
\hline $\begin{array}{l}\text { Fodder distribution and } \\
\text { livestock camps }\end{array}$ & $\begin{array}{l}1 \text { Agreed plan of action } \\
2 \text { Local government implementation } \\
\text { capacity } \\
3 \text { Resources }\end{array}$ & $\begin{array}{l}1 \text { Virually unknown in Ethiopla } \\
2 \text { Local government very weak } \\
3 \text { No resources }\end{array}$ \\
\hline
\end{tabular}


term rural development, especially in drought-prone areas. In so doing, they have filled a vacuum, deliberately created by government policy: the Mengistu regime withdrew resources from low potential areas, with World Bank support, in order to concentrate its efforts on Peasant Area Development Projects (PADEPs) in high potential areas. Presently, more than 80 NGOs operate in Ethiopia. In many districts, they are the dominant presence.

NGO activities have been controversial, in Africa generally and in Ethiopia. On the relief side, it has been argued that large-scale NGO operations bypass local government and often make subsequent development more difficult by poaching staff and creating new institutional structures (Buchanan.Smith 1990; Hubbard 1991). On the development side, also, NGOs are sometimes thought to be too independent.

The new Ethiopian disaster management policy reflects a sceptical view about the role of NGOs. It states that:

NGOinvolvement in relief projects shall be in the funding and implementation of such projects. The leading role in implementation shall, however, be played by the community or the beneficiaries under the co-ordination, direction and support of the relevant Line Departments. Guidelines as to the details of the involvement of NGOs in such projects shall be prepared by the RRC

(TGE 1993a :32)

This is a restrictive phrasing. It reflects a view in the Ethiopian Government that it was acceptable for NGOs to play such a large role under the previous regime, because this was the only channel through which many donors would supply aid, but that under the current Government, a different relationship is indicated. The Government now has a policy and, for relief at least, a detailed plan: the role of NGOs is to help implement the new policy.

The problem this poses for NGOs is two-fold. First, they see themselves, rightly, as the main source of experiment and innovation in rural development and relief management in Ethiopia. And, second, they see, again rightly, that the Government does not have the staff, logistical capacity or finance to replace NGOs for the foreseeable future.
A resolution of the dilemma will require a change in behaviour by both sides. If the Government is successful in encouraging diversity and in fostering experimentation and research, it will probably also become less nervous about new institutional forms pioneered by NGOs. In Ethiopia, which has traditionally had highly centralized Governments, this will be a big change: but it is one consistent with TGE constitutional objectives and with the principles on LRD set out earlier.

On the NGO side, it will be necessary to recognize the new role of Government and act to help strengthen its capacity. This means, for example, that NGO projects should routinely establish steering committees on which local government is represented, provide funds to equip, mobilize and train local government officials, and channel at least a part of resources through government institutions.

The RRC obviously has a part to play in this new set of relationships, but probably with a different role to the one it has played in the past: less of an implementing agency and resource controller, more of a mobilizing and coordinating agency and resource monitor. It has already begun to move in this direction. It is interesting that this new kind of role is foreseen both in recent literature on planning (Murray (ed.) 1992) and in the TGE's own NPDM. Here, the functions of the RRC are described largely in terms of co-ordinating information and channelling resources to line ministries, rather than in terms of direct implementation. The RRC Commissioner is Secretary of a National Disaster Prevention and Preparedness Committee, chaired by the Prime Minister and with the participation of seven line ministries and the Chairmen of the Regional Councils. It seems from the text (TGE 1993b: 10ff) that RRC is very deliberately not seen as a super-ministry of the kind that was tried and failed in some integrated rural development programmes of the 1970s and 1980s. This would certainly be in keeping with recent thinking about the role of food security units or poverty units, which are similarly enjoined to adopt largely a facilitating role (Maxwell 1989).

\section{CONCLUSION}

At first sight, LRD seems like undiluted common sense. It is. Nothing here should detract from the conclusion that LRD offers practical benefits to 
Ethiopia. The Government is right to stress the possibilities. However, LRD involves costs and trade-offs, there are questions about what is feasible in a poor country with weak state capacity, and the future role of NGOs is controversial. The discussion here suggests both operational conclusions and a research agenda.

The main operational conclusions are about the need for a step by step approach to planning LRD, with the first priority given to assuring an effective famine safety net and then building an LRD strategy from the bottom up. In a country as resource-starved and administratively weak as Ethiopia, the greatest risk is trying to do too much with LRD too quickly. NGOs have a role to play in this strategy, but will need to work closely with Government and set out explicitly to strengthen and support government capacity. The RRC will have a facilitating role.

The research agenda includes many detailed aspects of individual interventions, like the employment guarantee scheme. In addition, however, there are important questions about the costs and trade-offs inherent in different interventions, and about the pace and sequencing of LRD as a whole.

\section{REFERENCES}

Aylieff, J., 1993, 'Statistical summary of food aid deliveries to Ethiopia, 1977-1992', Food Aid Information Unit, World Food Programme, Addis Ababa, June

Belshaw, D., 1990, 'Food strategy formulation and development planning in Ethiopia', IDS Bulletin Vol 21 No 3, July

Blaikie, P., and Brookfield, H., 1987, Land Degradation and Society, London: Methuen

Buchanan-Smith, M., 1990, 'Food security planning in the wake of an emergency relief operation: the case of Darfur, Western Sudan', Discussion Paper 278, Brighton: IDS, July

CARE USA, CARE Ethiopia and USAID, 1993, 'Rapid assessment of the food and nutrition security impact of the CARE food programming activities in Eastern Shewa and Western Hararghe', mimeo, Addis Ababa, October

Chambers R., 1993, 'Rural appraisal: rapid, relaxed and participatory',Discussion Paper 311, Brighton: IDS, October

Clay, E.J., 1986, 'Rural public works and food for work: a survey', World Development, Vol 14 (10/11)

Debebe Habte-Wold and Maxwell, S., 1992, 'Vulnerability profiles and risk mapping in Ethiopia', mimeo, Food and Nutrition Unit, Ministry of Planning and Economic Development, Addis Ababa, Deœmber

FAO, 1994, 'Food supply situation and crop prospects in sub-Saharan Africa', Special Report No 2, Global Information and Early Warning System on Food and Agriculture, FAO, Rome

FEWS, 1994, Harvest Assessment, Famine Early Warning System for USAID, January

Gutu, Samia Zekaria, 1993, 'Cereal, pulse and oilseed balance sheet for Ethiopia: update', Food for Development Discussion Paper No 4, World Food Programme, Addis Ababa, August
Herbinger, W., 1993, 'WFP's experience with employmentbased food security safety-net in Ethiopia', Food for Development Discussion Paper No 2, World Food Programme, Addis Ababa, June

Hubbard, M., 1991, 'When and how famine prevention capability of rural local government in Western Sudan should be strengthened: lessons from the Kordofan experience' in S. Maxwell, (ed.), 1991, To Cure All Hunger: Food Policy and Food Security in Sudan, London: Intermediate Technology Publications

Lirenso, Alemayehu, 1993, 'Grain marketing reform in Ethiopia: a study of the impact of deregulation on the structure and performance of grain markets', DPhil thesis, University of East Anglia

Maxwell, S., 1989, 'Organizational issues in food security planning', mimeo, Institute of Development Studies, December

1992, 'Food security in Africa: priorities for reducing hunger', Africa Recovery Briefing Paper No 6, United Nations Department of Public Information, September

_-1993, 'Can a cloudless sky have a silver lining? The scope for an employment-based safety net in Ethiopia', Food for Development Discussion Paper No 1, World Food Programme, Addis Ababa

Maxwell, S and Belshaw, D., 1990, 'Food for development: new roles for food aid in Ethiopia', Report to WFP, Rome and Addis Ababa

Murray, R,(ed.), 1992,'New Forms of Public Administration', IDS Bulletin Vol 23 No 4

Transitional Government of Ethiopia, 1991, 'Ethiopia's economic policy during the transitional period', Addis Ababa, November

_ 1993a, 'Directives for disaster prevention and management, Addis Ababa, September 
- 1993b, 'National policy on disaster management', Addis Ababa, September

UNICEF, 1994, 'State of the World's Children, 1994', UNICEF, New York

von Braun, J., Teklu T. and Webb, P., 1992, 'Labour intensive public works for food security in Africa: past experience and f:ature potential', International Labour Review, Vol 131 No1

von Braun, J., Bouis, H., Kumar S. and Pandya-Lorch, R., 1992, 'Improving food security of the poor: concept, policy and programmes', International Food Policy Research Institute, Washington

Webb, P., von Braun J. and Yohannes, Y., 1992, 'Famine in Ethiopia: policy implications of coping failure at national and household level', Research Report No 92, International Food Policy Research Institute, Washington
Webb, P., Richardson, E., Seyoum S. and Yohannes, Y., 1994, 'Vulnerability mapping and geographical targeting. an exploratory methodology applied to Ethiopia', Report to USAID, January

World Bank, 1976,'Publicworks programmes in developing countries: a comparative analysis', World Bank Staff Working Paper No 224, Washington: World Bank

—, 1990, World Development Report 1990, Washington: World Bank

1993, Ethiopia: Toward poverty alleviation and a social action programme, World Bank, Washington, July

- 1994, World Development Report 1994, Washington: World Bank,

World Bank and World Food Programme, 1991, Food Aid in Africa: An agenda for the 1990s, Washington and Rome: World Bank and WFP, August 